\title{
Making Sense of 1917: Towards a Global History of the Russian Revolution
}

\author{
Matthew Rendle
}

It is clear that the global impact of the Russian Revolution over the last century has been immense, particularly as a source of inspiration for social movements across the world. What is less clear, however, is the global impact on the revolution. The influence of Europe's revolutionary tradition has long been recognized and the political culture of 1917 was deeply influenced by the ideas (civil liberties and rights), practices (popular protests and elections), and symbols (red flag, Marseillaise, Internationale, and May Day) that had emerged since the French Revolution. ${ }^{1}$ Contemporaries immediately situated the February Revolution of 1917 within the other examples of "upheaval" (perevorot) known in "world history." 2 One compared the soldiers' revolt on February 26-27 to the storming of the Bastille. ${ }^{3}$ Others published new accounts of previous revolutions to serve as lessons for Russia's future, whether stressing liberty, equality, and fraternity, highlighting the constitutions and republics emerging from 1848, or embracing the Paris Commune as an elective or socialist experiment. ${ }^{4}$ These influences continued after the October Revolution, with new festivals drawing from the revolutionary past and national holidays for key events like the Paris Commune, alongside a plan for an ambitious list of monuments to previous revolutionaries, from Marx and Engels to Danton and Robespierre. ${ }^{5}$ Familiarity with the French Revolution in particular, it has been argued, helped shape political discourse across the revolution; it misled many intellectuals who failed to appreciate the peculiarities of Russia's position in their constant search for a Russian Danton, Robespierre, or Bonaparte, whilst the Bolsheviks saw it as a source of ideas on how revolutions worked in practice. ${ }^{6}$ The Bolsheviks were also influenced by the Paris Commune as the first

1. B. I. Kolonitskii, Simvoly vlasti i bor' ba za vlast': k izucheniiu politicheskoi kul'tury rossiiskoi revoliutsii 1917 goda, 2nd ed. (St Petersburg, 2012).

2. V. M. Mikhailov, Pervaia nedelia Russkoi svobody (Moscow, 1917), 3.

3. I. S. Lukash, Volyntsy (Petrograd, 1917), 20-21.

4. For e.g., V. M. Lobanov, Frantsuzskaia revoliutsiia (Moscow, 1917); S. G. Lozinskii, Revoliutsiia 1848 g. v Avstrii (Petrograd, 1917); N. I. Kareev, Chem byla Parizhskaia kommuna 1871 goda? (Petrograd, 1917).

5. Youri Limonov, 'Les manifestations populaires de 1789-1793 en France et les grandioses festivités de 1917-1920 en Russie soviétique’ in A. Narotchnitski, ed., La Revolution Française et la Russie (Moscow, 1989), 378-99; Maria A. Burganova, "Monumental Sculpture in Russia in 1918-1919," Texts. Art and Literature Scientific and Analytical Journal, no. 2 (2015): 57-72.

6. John L. H. Keep, “1917: The Tyranny of Paris over Petrograd,” Soviet Studies 20, no. 1 (July 1968): 22-35; and Jay Bergman, "The Perils of Historical Analogy: Leon Trotsky on the French Revolution," Journal of the History of Ideas 48, no. 1 (January 1987): 73-98. For a more positive view, see George Jackson, "The Influence of the French Revolution on Lenin's Conception of the Russian Revolution," in Gail M. Schwab and John R. Jeanneny, eds. The French Revolution of 1789 and its Impact (Westport, CT, 1995), 273-84. See also Gabriel Schoenfeld, "Uses of the Past: Bolshevism and the French Revolutionary Tradition," in Schwab and Jeannery, French Revolution, 285-304. For surveys, see T. F. Kondrat'eva, 
proletarian revolution, and they portrayed October as its successor even as they drew inspiration and lessons from the Commune's failures. ${ }^{7}$

Beyond the revolutionary tradition, recent works have highlighted the continuation of ideas and practices across the revolutionary period in areas stretching from state practices to social welfare, and how these formed part of the broader onset of modernity across Europe. ${ }^{8}$ Similarly, the internationalism of the Bolsheviks has been reemphasized as their conception of Russia as at the vanguard of the proletarian world revolution affected various areas of domestic policy. ${ }^{9}$

There is, however, much more that can be said about global influences on the Russian Revolution if explorations of its origins and nature expand more systematically beyond Russia's borders and appreciate Russia's obvious participation in the processes of globalization in the decades prior to 1917, whether through its involvement in international affairs and wars, the connections tying its economy to others, or the circulation of ideas and concepts. The circulation of ideas alone in 1917 drew on a much larger range of global references than the revolutionary tradition to explain concepts and support arguments on issues ranging from political structures and constitutions, to land and workers' conciliation boards, to wages and the women's question. Many references were fleeting, but the frequency of certain examples suggests they became embedded in how particular topics were discussed and helped influence policy in these areas, a trend which continued after the October Revolution.

This article focuses on the circulation of ideas and concepts to explore how historians might study the global influences on the Russian Revolution and how such studies could extend our knowledge of this tumultuous period. There are limitations, of course, to what a "global" approach can unveil; a survey of recent research on the "inward influences" on the French Revolution revealed a "mixed case" on the extent to which these shaped the origins and

Bol'sheviki-Iakobintsy i prizrak termidora (Moscow, 1993); Alexander Tchoudinov, "The Evolution of Russian Discourse on the French Revolution," in Alan Forrest and Matthias Middell, eds. The Routledge Companion to the French Revolution in World History (London, 2016), 277-98; and the studies of Dmitry Shlapentokh: The French Revolution in Russian Intellectual Life, 1865-1905 (Westport, CT, 1996); The French Revolution and the Russian Anti-Democratic Tradition: A Case of False Consciousness (New Brunswick, NJ, 1997); and The Counter-Revolution in Revolution: Images of Thermidor and Napoleon at the Time of the Russian Revolution and Civil War (New York, 1999).

7. Jay Bergman, “The Paris Commune in Bolshevik Mythology," English Historical Review 129, no. 541 (December 2014): 1412-41; and Marion Sawer, "The Soviet Image of the Commune: Lenin and Beyond," in James A. Leith, ed. Images of the Commune (Montreal, 1978), 245-63.

8. See Daniel Beer, Renovating Russia: The Human Sciences and the Fate of Liberal Modernity, 1880-1930 (Ithaca, 2008); and David L. Hoffmann, Cultivating the Masses: Modern State Practices and Soviet Socialism, 1914-1939 (Ithaca, 2011). See also the unique attempt by Paul Dukes to integrate 1917 into world history, although he does not directly assess global influence on the revolutionary process in 1917, October and the World: Perspectives on the Russian Revolution (London, 1979).

9. Gleb J. Albert, "From 'World Soviet' to 'Fatherland of All Proletarians': Anticipated World Society and Global Thinking in Early Soviet Russia," InterDisciplines, no. 1 (2012): 85-119; and Gleb J. Albert, Das Charisma der Weltrevolution: Revolutionärer Internationalismus in der frühen Sowjetgesellschaft, 1917-1927 (Cologne, 2017). 
course of the revolution in comparison with the traditional focus on "internal" factors. ${ }^{10}$ It is also questionable to what extent influences were global. Although the world became more interconnected throughout the nineteenth century with rapid advances in communication, more structured ways of storing and distributing knowledge, and more uniform bodily practices, European concepts and institutions remained central, particularly for those in Europe. ${ }^{11}$ It is difficult, moreover, to trace firm connections between ideas, individuals, and actions (or, for that matter, between international events and contacts, and internal policies and developments), often forcing historians to rely on intuitive assessments. Any connections also vary in their intensity. One recent study proposed four levels of connectedness: initial, occasional and indirect contact; regular, ongoing interaction; sustained and large-scale interaction; and, finally, the integration of influences into a country's political, social, and cultural life, influencing events and mentalities. ${ }^{12}$ Clearly, many of the global references made by contemporaries in 1917 barely went past the first stage, with authors and speakers citing barely-understood examples as a quick means to reinforce an argument. Few influences became integrated into the revolution, truly shaping processes and directions.

Nevertheless, appreciating global influences on the revolution enables historians to better understand how contemporaries made sense of 1917, and rather than simply borrowing from the past to understand how to make a revolution, contemporaries from across the political spectrum searched widely for ideas on how to make a new country. This search reminds us of the belief in the potential of the revolution to drive progress, and how many felt the political, social, and cultural isolation of Russia on the world stage had now ended. Russia was catching up with the modern world and taking the best ideas from around the world, which in turn could enable it to take a leading role. These sentiments moved beyond political discourse to embrace how people conceived of broader social and cultural progress. Debates over key issues like peace, land, workers' rights, and gender equality took place in a global context, even if this did not always percolate down to villages or factories.

This was clearest in discussions of political structures, which almost always reference other countries, even if fleetingly. ${ }^{13}$ One political handbook

10. David Bell, “Questioning the Global Turn: The Case of the French Revolution,” French Historical Studies 37, no. 1 (Winter 2014): 1-24. For a more positive assessment, see Alan Forrest and Matthias Middell, "Introduction," in The Routledge Companion, 1-20. For pioneering studies, see Suzanne Desan, Lynn Hunt, and William Max Nelson, eds. The French Revolution in Global Perspective (Ithaca, 2013); and Lynn Hunt, "The French Revolution in Global Context," in David Armitage and Sanjay Subrahmanyam, ed. The Age of Revolutions in Global Context, c. 1760-1840 (Basingstoke, 2010), 20-36.

11. C. A. Bayly, The Birth of the Modern World, 1780-1914: Global Connections and Comparisons (Malden, Mass, 2004), 12-20; and Jürgen Osterhammel, The Transformation of the World: A Global History of the Nineteenth Century, trans. Patrick Camiller (Princeton, 2014), 9-43, 712-24.

12. James Belich, John Darwin, and Chris Wickham, "Introduction: The Prospect of Global History," in James Belich, John Darwin, Margret Frenz, and Chris Wickham, eds. The Prospect of Global History (Oxford, 2016), 5.

13. For a discussion of this topic that appreciates the role of global references, see Ian Thatcher, "The Russian Revolutionary Constitution and Pamphlet Literature in the 1917 
noted that most countries were constitutional monarchies (referencing England), before moving to "representative" republics (France and the USA) and "direct" republics (Switzerland), with similarities between some republics (France) and constitutional monarchies (Italy). The handbook then discussed legal systems (referencing England, Germany, Holland, Sweden, Norway, Italy, Denmark, Belgium, Spain, Austria, and Greece) before more detailed coverage of political systems briefly widened the net to Haiti before devoting sections to Austria-Hungary, the US, England, Germany, Italy, France, and Switzerland. A final section on political thought focused on Europeans, with a quick nod to Arabic and Chinese thought. ${ }^{14}$ Other pamphlets followed suit, referencing between them every region in Europe, from Andorra and Bulgaria to Montenegro and Sweden. Alongside France, England was the most common, with 1215 (Magna Carta), 1679 (the Habeas Corpus Act), 1688 (the "Glorious" Revolution), 1832 (electoral reform), and 1911 (House of Lords reform) forming political landmarks. ${ }^{15}$ Another common example was Switzerland, whose system of federal cantons, referenda, and trilingual culture clearly resonated with Russians searching for a means to incorporate the diversity of the empire into a functioning democracy. ${ }^{16}$ Most discussions, though, confined references to non-European countries to a few obvious examples, usually Australia and the US, with pamphlets advocating gender equality recognizing and exploring the varying legislation in different US states. ${ }^{17}$ Only a few authors ventured further afield, usually briefly to South America, China, or Japan.

An almost identical range of countries was used to provide examples for other topics, ranging from land and social reform, working hours and urban self-government, to civil rights, equality, and freedom of belief. Some authors advocated reforms on the basis of supposed success elsewhere. A study of conciliation courts (primiritel'nye kamery) advanced their use by workers as a weapon and a means to avoid the usual strikes and lock-outs. The origin of similar courts in various places in France, especially in the fourteenth and fifteenth centuries, was explored, as was their further development in Europe, with mention of various countries and examples of different typesboards of conciliation versus boards of arbitration-taken from England, Germany, Holland, Switzerland, Sweden, Norway, and Denmark. Other variations were drawn from further afield: the US, Canada, New Zealand, and, in detail, Australia. ${ }^{18}$ Another pamphlet on the minimum wage took a similar approach, discussing the laws in Melbourne (and Victoria province)

Russian Revolution,” Europe-Asia Studies 68, no. 10 (December 2016): 1635-53.

14. Politicheskii spravochnik svobodnago Rossiiskago grazhdanina (Moscow, 1917), 8-33, 56-71.

15. For e.g., I. L. Nikolin, Konstitutsii Anglii i Frantsii (Moscow, 1917); and S. I. Tkhorzhevskii, Gosudarstvennyi stroi Anglii (Petrograd, 1917).

16. For e.g., I. Danilovich, Shveitsarskaia federatsiia (Petrograd, 1917); and Ol'govich [O. A. Vol'kenshtein], Shveitsariia, strana istinnoi demokratii (Petrograd, 1917).

17. For e.g., L. Gurevich, Pochemu nuzhno dat' zhenshchinam takiia zhe prava, kak muzhchinam (Petrograd, 1917); and O. A. Vol'kenshtein, Osvobozhdenie zhenshchiny (Petrograd, 1917).

18. V. V. Sviatlovskii, Primiritel'nyia kamery (Petrograd, 1917). 
extensively, and Europe, especially England, to argue the need for something similar in Russia. ${ }^{19}$

The extent to which these references spread from politicians and intellectual elites to the broader population is difficult to ascertain. There was a voracious appetite for information throughout the revolution, even to the extent of consuming all manner of rumors. From February onwards, successive governments launched enlightenment and educational campaigns to spread literacy, ideas, and resources across Russia. Contemporaries invariably talk of reading national and local newspapers, and bemoan their frequent absences; the relatively privileged spent hours reading papers each day, but even some peasants regularly came across papers. Hundreds of pamphlets made views from across the political spectrum accessible and were published in millions of copies at reasonable prices. ${ }^{20}$ People listened to innumerable speeches on the streets, in factories or in meetings. Sensational lectures on the personality of Nicholas II or the depravity of Rasputin were packed, but so too were serious lectures. The liberal historian and pamphleteer, Nikolai I. Kareev, described a hectic schedule: popular lectures on historical topics like the French Revolution and the Declaration of the Rights of Man; university lectures for officials and the broader public; lectures for soldiers and trainees; lectures in factories for workers; and more. ${ }^{21}$

At the moment, we have only odd glimpses into how people related to the global. People quickly adopted the new (non-Russian) revolutionary language for various reasons, whilst the more enthusiastic gave their children "revolutionary" names, many of which were inspired by the revolutionary tradition (from Marat to Rosa Luxemburg), the enthusiasm for world revolution or, occasionally, solidarity with international events. ${ }^{22}$ In a letter to the authorities, one worker criticized the new repressive "bourgeois" state structure after the February Revolution, claiming the people had heard promises of freedom before: in Ancient Greece and the Roman Empire; medieval Novgorod; France, England, Italy, Austria, and Germany (perhaps thinking of the nineteenthcentury revolutions); and in Asia and America. More strikingly, he noted that previously Russia had been forced to draw facts from the "political history" of western Europe, but now, thanks to the revolution, there was no need to venture abroad as the facts were at home in front of people. Other letters, though, simply provide hints as to some sort of influence by using phrases such as "liberty,

19. K. A. Pazhitnov, Minimal'naia zarabotnaia plata (Petrograd, 1917).

20. Almost 29 million copies of over 550 "socialist" pamphlets were published in Petrograd alone, with 11 million copies of over 250 "bourgeois" pamphlets: Orlando Figes and Boris Kolonitskii, Interpreting the Russian Revolution: The Language and Symbols of 1917 (New Haven, 1999), 7. For more details, see B. I. Kolonitskii, "Izdatel'skaia deiatel'nost' vremennogo komiteta gosudarstvennoi dumy v Petrograde (mart-oktiabr' 1917g.)” in O. N. Ansberg, ed., Knizhnoe delo v Rossii vo vtoroi polovine XIX-nachale XX veka. Sbornik nauchnykh trudov. Vyp. 5 (Leningrad, 1990), 56-67.

21. N. I. Kareev, Prozhitoe i perezhitoe (Leningrad, 1990), 263-64.

22. A. M. Selishchev, Iazyk revoliutsionnoi epokhi: Iz nabliudenii nad russkim iazykom (1917-1926) (Moscow, 1928; reprint 2010); B. I. Kolonitskii, “'Revolutionary Names': Russian Personal Names and Political Consciousness in the 1920s and 1930s," Revolutionary Russia 6, no. 2 (1993): 210-28. 
equality, and fraternity" or in their demands for information. ${ }^{23}$ The unusual diary of a peasant from Vologda province, A. A. Zamarev, provides similar glimpses. It is dominated by comments on the weather and everyday activities, and, unsurprisingly, he reads about the land question. But he also reads national and local papers, attends meetings and is aware of national events, and welcomes the opening of a "people's house" nearby with books and papers. He comments on his reading occasionally, marveling that St. Peter's Basilica in Rome is apparently as big as the Kazan' and St. Isaak cathedrals in Petrograd together, that Spain is so warm, and at Edward Jenner's medical advances. ${ }^{24}$ All this, as one historian reading the same diary has reminded us, indicates a desire at some level to seek connections to the wider world..$^{25}$

Unsurprisingly, the educated classes were more likely to take a broader perspective. Iurii V. Got'e, as might be expected from a specialist on early Russian history, talked repeatedly of a new "time of troubles" and the "Pugachevshchina" of the crowds, but he also made a rare reference to a recent revolution, with the Kornilov Revolt reminding him of the Mexican Revolution. ${ }^{26}$ Nikita P. Okunev, a Moscow businessman, read about republics, but favored a constitutional monarchy of the "English type"; compared Russia despondently to France in 1847-49; questioned Kornilov's ability to be a "Napoleon"; quoted the French socialist Jean Jaurès that revolution is the most "barbaric" form of progress; and feared the Bolsheviks would launch a "St. Bartholomew's Day" massacre against the middle classes (referring to the mass murder of protestants in sixteenth-century France). ${ }^{27}$ What might be more indicative of mentalities is what people chose to read. Got'e read works on wars, Guy de Maupassant (on Paris during the Commune), Petr Chaadaev, Marquis de Custine (a critical observer of tsarist Russia), and Hippolyte Taine (on 1848-51), among others. Throughout, he comments on the similarities with current events. ${ }^{28}$ His colleague, Stepan B. Veselovskii, also referred to the "time of troubles" and the Polish occupation of Moscow in 1611, drew comparisons with 1688, 1789, and Napoleon; and read pertinent works, quoting approvingly from Edmund Burke's condemnation of the violence of the French Revolution, and re-reading Georges Renard and Alexis de Tocqueville on 1848. ${ }^{29}$

These may only be the comments of individuals, but the prevalence of such comments suggest these reference points achieved a sufficient level of immersion into educated culture to influence mentalities and actions. It has 287.

23. Mark D. Steinberg, Voices of Revolution, 1917 (New Haven, 2001), 86-87, 114-15,

24. Dnevnik Totemskogo krest'ianina A. A. Zamareva. 1906-1922 gg. (Moscow, 1995), 158, 173, 186, 197, 201.

25. Corinne Gaudin, "Circulation and Production of News and Rumor in Rural Russia during World War I," in Murray Frame, Boris Kolonitskii, Steven Marks, and Melissa Stockdale, eds. Russian Culture in War and Revolution, 1914-1922: Book 2: Political Culture, Identities, Mentalities, and Memory (Bloomington, 2014), 70-71.

26. I. V. Got'e, Time of Troubles: The Diary of Iurii Vladimirovich Got'e, ed. and trans. Terence Emmons (London, 1988), 35, 42, 45, 56, 78, 109, 120, 164-65, 179, 192.

27. N. P. Okunov, Dnevnik Moskvicha (1917-1924) (Paris, 1990), 28, 61, 75, 87, 95.

28. Got'e, Time of Troubles, 47, 52, 94, 99-100, 166-67, 295, 298-301.

29. S. B. Veselovskii, “Dnevniki, 1915-1923, 1944 godov,” Voprosy istorii, no. 6 (2000): 97-99, 106; no. 8 (2000): 88, 96, 102, 104; no. 9 (2000): 117. 
often been argued that the lessons of 1789 (particularly the fear of civil war and terror) helped persuade moderate socialists not to seek power after February, whilst those involved in the Provisional Government were clearly conceptualizing issues in ways similar to the pamphlets, not least because many officials also wrote pamphlets. This is particularly clear in the preparations for the Constituent Assembly. From the start, the Special Council charged with organizing the elections shared the determination of pamphleteers, as noted above, to search the globe for examples of political structures. In successive discussions on who should be eligible to vote, for instance, officials discussed the minimum age, criminal convictions, and mental illness with numerous references to other countries. The minimum age discussion ranged from Australia and New Zealand to the US, Brazil, and Japan, revealing a range of practices that informed the final decision. Subsequent decisions on whether to adopt majority voting or proportional representation followed suit. ${ }^{30}$ In summarizing the decision in favor of the latter, the Council noted that it had "thoroughly" examined all existing electoral systems to see which suited Russia's territorial, ethnic, and cultural diversity, and met the need for fair and rapid elections. ${ }^{31}$ Similarly, thorough debates continued into the autumn of 1917 with discussions over the relationship of the Assembly to the Provisional Government after its formation and the value of an upper and lower chamber in any future political structure. ${ }^{32}$ Elsewhere, Germany and England were cited to justify growing state intervention in the economy, and whilst published legislation on conciliation and arbitration chambers did not use examples like the pamphlet cited above, the Minister of Labor's assertion in August 1917 that the new labor laws marked a "great step forward" from much of Europe is suggestive. ${ }^{33}$ Ultimately, only a systematic examination of all the documents behind major policies will reveal the true extent of global influences on them, but it seems likely the globalization of 1917 in public discourse fed into policy, given that many of the same individuals participated in both.

The same trends are evident after the October Revolution. On the one hand, previous revolutions continued to inspire. Economic theorists devoted books to examining the French Revolution for ideas on how to avoid hyperinflation, whilst Lenin famously drew heavily on the experiences of 1848-51 and the Paris Commune to inform his views on the structure of the state and the value of violence. ${ }^{34}$ On the other hand, Bolshevik leaders and theorists

30. Osoboe soveshchanie dlia izgotovleniia proekta polozheniia o vyborakh $v$ uchreditel'noe sobranie. I. Proekt razdela I (glav I-V) polozheniia o vyborakh v uchreditel'noe sobranie (Petrograd, 1917), 1-41. The eleven issues of the Council's Stenograficheskii otchet (published from May 25- June 15), reveal the debates in more detail and indicate that many of those officials highlighting other countries also wrote pamphlets on similar topics.

31. Aleksandr Fyodorovich Kerenskii and Robert P. Browder, eds., The Russian Provisional Government, 1917: Documents, 3 vols. (Stanford, 1961), 1:441-45.

32. N. Rubinshtein, "Vremennoe Pravitel'stvo i Uchreditel'noe Sobranie," in Krasnyi arkhiv, no. 28 (1928), 110-15, 132-38. 43, 746.

33. Kerenskii and Browder, The Russian Provisional Government, 2:674-77, 713, 742-

34. Schoenfeld, “Uses,” 294-95, 301-2; V. I. Lenin, The State and Revolution (1917), available at https://www.marxists.org/archive/lenin/works/1917/staterev/index.htm (last accessed June 19, 2017) 
drew on developments elsewhere as markers of modernity, whether the ideas of Taylorism in the US and attempts to approach the problem of productivity scientifically, or broader developments in areas such as health, social welfare, and state-sponsored violence and surveillance. ${ }^{35}$ The global became important not simply as a source of ideas and inspiration, but as a marker to meet and surpass, thereby proving the advanced nature of the new soviet state.

This was certainly true of the new soviet legal system. On November 24, 1917, the Bolsheviks abolished existing courts, establishing people's courts for regular crimes and revolutionary tribunals for "counter-revolutionary" crimes. Both were to rely on revolutionary consciousness to reach a verdict and existing laws were formally abolished a year later. Petr I. Stuchka, legal theorist and Commissar of Justice in 1918, boasted in 1919 that the revolution had cast all sixteen volumes of the law codes of the Russian empire on the bonfire along with "bourgeois" concepts of law. ${ }^{36}$ By 1922, however, Stuchka was forced to deny that the growing complexity of the legal system, culminating in new law codes in 1922, marked a return to the tsarist system. ${ }^{37}$ Yet the new legal system did not only draw heavily on tsarist laws, which in turn had been influenced by European legal systems, but it was also inspired directly by Europe. This was hardly surprising. Most Soviet legal theorists, including Stuchka, had trained as lawyers prior to 1917 and were well-versed in the ideas of European legal thought, and these influences are visible in their conceptions of revolutionary consciousness, penal policy, criminology, and other issues. Moreover, the Bolsheviks required law to perform similar functions as in other countries and thus adopted similar practices, whether lawyers, courts, procedure, or language. Even the supposed "revolutionary" elements usually had earlier precedents; revolutionary tribunals drew consciously from the French Revolution, whilst the well-quoted phrase from the civil code of 1922-"the law protects private rights except in so far as they are exercised in contradiction to their social and economic purpose"-was inspired by Hungarian and French theorists and, when later applied, usually resulted in decisions that would have been reached by non-socialist courts. ${ }^{38}$ Similarly, whilst the criminal and civil codes of 1922 did draw heavily from previous codes, Lenin instructed the Commissariat of Justice to take "everything in the literature and experience" of western Europe that protected working people, but not to be limited by this, with the intention that the codes

35. Richard Stites, Revolutionary Dreams: Utopian Vision and Experimental Life in the Russian Revolution (Oxford, 1989); Hoffmann, Cultivating the Masses.

36. P. I. Stuchka, "Proletarian Law (1919)," in Robert Sharlet, Peter B. Maggs, and Piers Beirne, eds., P. I. Stuchka: Selected Writings on Soviet Law and Marxism (Armonk, NY, 1988), 11.

37. P. I. Stuchka, "Five Years of Revolution in Law (1922)," in William G. Rosenberg, ed. Bolshevik Visions: First Phase of the Cultural Revolution in Soviet Russia, 2 vols. (Ann Arbor, 1984; reprint, 1990), 1: 195.

38. N. V. Krylenko, "Vozniknovenie i pervye mesiatsy raboty revoliutsionnykh tribunalov," in N. V. Krylenko, ed. Problemy ugolovnoi politiki, 4 vols. (Moscow, 1935-37), 3:30-31; John N. Hazard, "Law and Tradition in the New Russia," Oxford Slavonic Papers 4 (1953): 141-42. 
should go further than their predecessors at home and abroad. ${ }^{39}$ As a consequence, one scholar has argued that an outside observer would find many basic principles, doctrines, strands of law, and procedures similar to those in Germany, France, Italy, England, and the US, and deliberately so. ${ }^{40}$ Another has argued more contentiously that the end result, in turn, later shaped developments in western law. ${ }^{41}$

Overall, the global impact of the revolution is more understandable if we recognize how 1917 emerged from global processes-enlightenment thinking, industrialization, and the onset of modernity-and was influenced by the ideas and practices it took from elsewhere. This article has only had space to scratch the surface and the extent of this influence remains unclear, whilst the internal factors emphasized by historians clearly remain of paramount importance. Nevertheless, contemporaries viewed their revolution as having global significance. They also examined other countries for inspiration when debating important issues and searching for new ideas, and evidence for old ones, and the results shaped their beliefs and actions. A global history of the Russian Revolution, therefore, can help historians understand the influences behind discourse, beliefs, practices, and policies. It can also help us appreciate how people made sense of 1917, and this is equally important in understanding the experiences and emotions generated by the revolution.

39. N. S. Timasheff, "The Impact of the Penal Law of Imperial Russia on Soviet Penal Law," American Slavic and East European Review 12, no. 4 (December 1953): 441-62; V. I. Lenin, Collected Works. 47 vols. (Moscow, 1960-70), 33:203.

40. Harold J. Berman, Justice in the USSR: An Interpretation of Soviet Law (Cambridge, Mass., 1963), 278.

41. John Quigley, Soviet Legal Innovation and the Law of the Western World (Cambridge, 2007). 